\title{
HUBUNGAN KARAKTERISTIK PENJAMU DAN BREEDING PLACE DENGAN KEJADIAN DBD DI KABUPATEN SERDANG BEDAGAI
}

\author{
Hetti Citra Marbun, Sri Malem Indirawati dan Nurmaini \\ Universitas Sumatera Utara, Indonesia \\ Email: hetticitra88@gmail.com, srimalem@usu.ac.id,dan nurmainik@yahoo.com
}

\begin{abstract}
DBD (Dengue Hemorrhagic Fever) is atransmitted disease caused by dengue virus and transmitted by Aedes aegypti mosquito. There were 183 cases of DBD in Serdang Bedagai Regency with one of them died in 2019 (Incidence Rate of 29.6 per 100,000 inhabitants and $C F R=0,5)$. The objective of the research was to analyze the correlation of age factor (0 months - 17 years) and breeding places with the incidence of DBD in children in Serdang Bedagai Regency, in 2020. The research used observational analytic method with case control design. The samples were 24 respondents in the case group and 24 respondents in the control group. The data were gathered by conducting observation and interviews and analyzed by using univariate analysis and bivariate analysis with chi square test. The result of bivariate analysis showed that there was the correlation of using mosquito coils at $(O R=$ 4,580), behavior of combating mosquito breeding place at $(O R=3,100)$ and breeding places at $(O R=4,000)$ with the incidence of DBD. Meanwhile, there is no correlation of age at $(p=1,000)$ and gender at $(p=0,511)$ with the incidence of DBD. So, that it is recommended that people of Serdang Bedagai Regency always use mosquito repellent at home but is not recommended to use mosquito coils because it is not environmentally friendly and people should use lotion, electric, spraying and preferably at home using gauze. Reducing water reservoirs, drain TPA routinely, and eradicating mosquito nests once a week.
\end{abstract}

Keywords: characteristic host; dengue hemorrhagic fever; aedes aegypti; breeding place

\section{Abstrak}

Penyakit demam berdarah dengue (DBD) merupakan penyakit menular yang disebabkan oleh virus dengue, ditularkan oleh nyamuk Aedes aegypti. Kabupaten Serdang Bedagai merupakan daerah endemis DBD. Pada tahun 2019 jumlah kasus DBD sebanyak 183 kasus dengan 1 kasus meninggal (Incidence Rate 29,6 per 100.000 penduduk dan CFR $=0,5$ ). Tujuan penelitian ini adalah untuk menganalisis hubungan karakteristik penjamu dan breeding place dengan kejadian demam berdarah dengue di Kabupaten Serdang Bedagai Tahun 2020. Metode penelitian adalah analitik observasional dengan desain case control. Sampel penelitian adalah anak yang berusia 0 bulan sampai 17 tahun yang berjumlah 84 orang. Pengumpulan data melalui wawancara dan observasi. Analisis data dilakukan secara univariat dan bivariat menggunakan uji chi-square. Berdasarkan analisis bivariat menunjukkan adanya hubungan kebiasaan memakai obat anti nyamuk $(\mathrm{OR}=4,580)$, perilaku pemberantasan sarang nyamuk $(\mathrm{OR}=3,100)$ dan keberadaan breeding place dengan $(\mathrm{OR}=4,000)$. Sementara itu tidak ada hubungan umur dan jenis kelamin

\begin{tabular}{lllll}
\hline How to cite: & Marbun, Hetti Citra., et. al. (2021) Hubungan Karakteristik Penjamu dan Breeding Place dengan \\
& Kejadian DBD di Kabupaten & Serdang & Bedagai, & Syntax Idea \\
& http://dx.doi.org/10.36418/syntax-idea.1144 & & \\
E-ISSN: & 2684-883X & & \\
Published by: & Ridwan Institute & & & \\
& &
\end{tabular}


dengan kejadian DBD. Maka, dari hasil penelitian tersebut disarankan bagi masyarakat Kabupaten Serdang Bedagai agar selalu membiasakan memakai obat anti nyamuk di rumah namun tidak disarankan menggunakan obat anti nyamuk bakar dikarenakan tidak ramah lingkungan dan sebaiknya masyarakat menggunakan lotion anti nyamuk, elektrik, obat anti nyamuk semprot dan sebaiknya di rumah menggunakan kawat kasa. Mengurangi tempat penampungan air, menguras TPA secara rutin, dan melakukan pemberantasan sarang nyamuk seminggu sekali.

Kata Kunci: karakteristik penjamu; demam berdarah dengue; aedes aegypti; breeding place

\section{Pendahuluan}

Demam berdarah dengue atau disingkat DBD adalah penyakit menular akibat virus yang dibawa oleh nyamuk Aedes Aegypti. Demam berdarah dengue masih menjadi masalah kesehatan masyarakat utama di seluruh daerah tropis dan sub-tropis di dunia dengan peningkatan 30 kali lipat dalam insiden global selama 50 tahun terakhir. World Health Organization (WHO) memperkirakan bahwa 2,5 miliar atau $40 \%$ populasi di dunia berisiko terhadap penyakit DBD terutama yang tinggal di daerah perkotaan di negara tropis dan subtropis (World Health Organization WHO, 2015)

Menurut Kementerian Kesehatan RI, Pada tahun 2019 penderita sebanyak 13.683 orang dan meninggal 133 jiwa per 29 Januari 2019 (Incidence Rate 5,08 per 100.000 penduduk dan CFR = 0,94\%) (Kementerian Kesehatan RI, 2019).

Faktor yang berperan dalam timbulnya penyakit berdasarkan segitiga epidemiologi dipengaruhi oleh faktor manusia sebagai host, lingkungan (environtment) termasuk nyamuk Aedes Aegypti sebagai vektor penularan DBD. Faktor host (penjamu) yaitu kerentanan dan respon imun seseorang sedangkan faktor lingkungan yaitu semua unsur di luar faktor individu penjamu yang memengaruhi status kesehatan populasi (faktor sosial ekonomi, lingkungan biologi dan lingkungan fisik) (Golberg, 1999).

Faktor lingkungan sangat mempengaruhi kejadian DBD karena nyamuk sering bertelur pada musim penghujan. Keberadaan tempat penampungan air atau kontainer (tempayan, bak mandi, drum, ember, dispenser, talang/saluran air, tendon belakang kulkas, tempa minum hewan peliharaan dan ban bekas), akan menjadi faktor pendukung perkembangbiakan nyamuk, karena akan menjadi tempat bertelur nyamuk Aedes aegypti. Setelah menjadi nyamuk dewasa, nyamuk Aedes Aegypti yang membawa virus dengue akan dapat menyebarkan virus dari satu orang ke orang lain sehingga membuat kasus DBD menyebar dengan cepat.

Kondisi di Kabupaten Serdang Bedagai yang merupakan salah satu daerah endemis DBD dan sesuai dengan data Dinas Kesehatan Kabupaten Serdang Bedagai jumlah kasus DBD yang terjadi di tahun 2017 sebanyak 86 kasus, pada tahun 2018 sebanyak 183 kasus dan pada tahun 2019 jumlah kasus DBD tetap sama tidak ada perubahan sebanyak 183 kasus dengan 1 kasus meninggal (Incidence Rate 29,6 per 100.000 penduduk dan CFR = 0,5\%) (Serdang Bedagai, 2018). 
Berdasarkan fakta yang telah diuraikan di atas, penelitian ini bertujuan untuk menganalisis hubungan karakteristik penjamu dan breeding place di Kabupaten Serdang Bedagai Tahun 2020.

\section{Metode Penelitian}

Jenis penelitian ini adalah penelitian analitik observasional dengan desain case control. Sampel penelitian ini diambil dengan menggunakan cluster sampling, proses pengambilan sampel ini dilakukan secara bertingkat karena jumlah populasi sangat besar dan menempati daerah yang sangat luas, sehingga diambil $30 \%$ dari seluruh kecamatan yang ada di Kabupaten Serdang Bedagai yang berjumlah 17 kecamatan. Pemilihan kecamatan menggunakan teknik purposive sampling. Kecamatan dipilih berdasarkam kasus tertinggi dan terendah, sehingga diperoleh lima kecamatan yakni kecamatan Perbaungan (Puskesmas Plus Perbaungan), Sei Rampah (Puskesmas Sei Rampah), Sei Bamban (Puskesmas Kampung Pon), Sipispis (Puskesmas Sipispis), dan Serbajadi (Puskesmas Kuala Bali). Perbandingan jumlah sampel kasus dan kontrol yang digunakan dalam penelitian ini adalah 1:1 yaitu kasus berjumlah 42 orang dan kontrol berjumlah 42 orang, total keseluruhan sampel penelitian ini adalah sebanyak 84 orang.

Waktu penelitian ini adalah bulan November 2019 sampai dengan bulan April 2020 dengan lokasi penelitian dilaksanakan di Wilayah Kabupaten Serdang Bedagai.

\section{Hasil dan Pembahasan}

\section{A. Hasil}

Tabel 1

Distribusi frekuensi karakteristik penjamu dan breeding place dengan kejadian demam berdarah dengue di Kabupaten Serdang Bedagai pada tahun 2020

\begin{tabular}{|c|c|c|}
\hline Karakteristik Responden & $n=84$ & $\%$ \\
\hline \multicolumn{3}{|l|}{ Umur } \\
\hline$<8$ Tahun & 19 & 22.6 \\
\hline$\geq 8$ Tahun & 65 & 77.4 \\
\hline \multicolumn{3}{|l|}{ Jenis Kelamin } \\
\hline Laki-laki & 46 & 54.8 \\
\hline Perempuan & 38 & 45.2 \\
\hline $\begin{array}{l}\text { Kebiasaan Memakai Obat } \\
\text { Nyamuk }\end{array}$ & & \\
\hline Kurang Baik & 37 & 44.0 \\
\hline Baik & 47 & 56.0 \\
\hline \multicolumn{3}{|l|}{ Perilaku PSN } \\
\hline Tidak Melakukan PSN & 51 & 60.7 \\
\hline Melakukan PSN & 33 & 39.3 \\
\hline \multicolumn{3}{|l|}{ Keberadaan Breeding Place } \\
\hline Ada & 42 & 50.0 \\
\hline Tidak ada & 42 & 50.0 \\
\hline
\end{tabular}


Dari hasil analisis univariat yang tergambar pada tabel 1 pada variabel umur diketahui bahwa responden yang berumur kurang 8 tahun sebanyak 19 orang $(22,6 \%)$ dan yang berumur besar sama dengan 8 tahun sebanyak 65 orang $(77,4 \%)$. Pada variabel jenis kelamin diketahui bahwa responden yang berjenis kelamin lakilaki yaitu sebanyak 46 orang $(54,8 \%)$ dan yang berjenis kelamin perempuan sebanyak 38 orang $(45,2 \%)$.

Pada variabel kebiasaan memakai obat anti nyamuk diketahui bahwa anak yang memiliki kebiasaan memakai obat anti nyamuk yang kurang baik yaitu sebanyak 37 orang $(44,0 \%)$ dan yang memiliki kebiasaan memakai obat anti nyamuk yang baik sebanyak 47 orang $(56,0 \%)$. Pada variabel perilaku pemberantasan sarang nyamuk diketahui bahwa responden yang tidak melakukan pemberantasan sarang nyamuk yaitu sebanyak 51 orang $(60,7 \%)$ dan yang melakukan pemberantasan sarang nyamuk sebanyak 33 orang $(39,3 \%)$.

Pada variabel breeding place rumah responden yang terdapat keberadaan breeding place yaitu sebanyak 42 orang $(50,0 \%)$ dan rumah responden yang tidak terdapat keberadaan breeding place nya yaitu sebanyak 42 orang $(50,0 \%)$.

Tabel 2

Distribusi frekuensi keberadaan breeding place dengan kejadian demam berdarah dengue di Kabupaten Serdang Bedagai pada tahun 2020

\begin{tabular}{lcccc}
\hline \multirow{2}{*}{ Keberadaan Breeding Place } & \multicolumn{2}{c}{ Ada } & \multicolumn{2}{c}{ Tidak Ada } \\
\cline { 2 - 5 } & $\mathbf{N}$ & $\mathbf{\%}$ & $\mathbf{N}$ & $\mathbf{\%}$ \\
\hline Tempayan & 7 & 8.3 & 77 & 91.7 \\
\hline Bak Mandi & 82 & 97.6 & 2 & 2.4 \\
\hline Drum & 50 & 59.5 & 34 & 40.5 \\
\hline Ember & 79 & 94.0 & 5 & 6.0 \\
\hline Dispenser & 65 & 77.4 & 19 & 22.6 \\
\hline Talang/Saluran Air & 44 & 52.4 & 40 & 47.6 \\
\hline Tendon Belakang Kulkas & 33 & 39.3 & 51 & 60.7 \\
\hline $\begin{array}{l}\text { Tempat Minum Hewan } \\
\text { Peliharaan }\end{array}$ & 79 & 94.0 & 5 & 6.0 \\
\hline Ban Bekas & 33 & 39.3 & 51 & 60.7
\end{tabular}

Berdasarkan tabel 2 dapat dilihat distribusi frekuensi keberadaan breeding place. Untuk keberadaan breeding place jenis tempayan yang ditemukan di rumah ada $7(8,3 \%)$, jenis ember ada $79(94,0 \%)$, jenis dispenser ada $65(77,4 \%)$, jenis talang/saluran air ada $44(52,4 \%)$, jenis tendon belakang kulkas ada $33(39,3 \%)$, jenis tempat minum hewan peliharaan ada $79(94,0 \%)$, jenis ban bekas ada $33(39,3 \%)$. 
Tabel 3

hubungan karakteristik penjamu dan keberadaan breeding place dengan kejadian demam berdarah dengue di Kabupaten Serdang Bedagai pada tahun 2020

\begin{tabular}{|c|c|c|c|c|c|c|c|c|}
\hline \multirow{3}{*}{ Variabel } & \multicolumn{6}{|c|}{ Kejadian Demam Berdarah Dengue } & \multirow{3}{*}{$\begin{array}{c}\text { p. } \\
\text { valu } \\
\text { e } \\
\end{array}$} & \multirow{3}{*}{$\begin{array}{c}\text { OR } \\
(95 \% \\
\text { CI }) \\
\end{array}$} \\
\hline & \multicolumn{2}{|c|}{ DBD } & \multicolumn{2}{|c|}{ Tidak DBD } & \multicolumn{2}{|c|}{ Total } & & \\
\hline & $\mathbf{N}$ & $\%$ & n & $\%$ & $\mathbf{N}$ & $\%$ & & \\
\hline \multicolumn{7}{|l|}{ Umur } & \multirow{3}{*}{$\begin{array}{c}1,00 \\
0\end{array}$} & \multirow{3}{*}{$\begin{array}{c}1,146 \\
(0,412- \\
3,189) \\
\end{array}$} \\
\hline$<8$ Tahun & 10 & 52,6 & 9 & 47,4 & 19 & 100,0 & & \\
\hline$\geq 8$ Tahun & 32 & 49,2 & 33 & 50,8 & 65 & 100,0 & & \\
\hline \multicolumn{8}{|l|}{ Jenis Kelamin } & \multirow{3}{*}{$\begin{array}{c}1,471 \\
(0,620- \\
3,487)\end{array}$} \\
\hline Laki-laki & 25 & 54,3 & 21 & 45,7 & 46 & 100,0 & 0,51 & \\
\hline Perempuan & 17 & 44,7 & 21 & 55,3 & 38 & 100,0 & 1 & \\
\hline \multicolumn{8}{|c|}{ Kebiasaan Memakai Obat Anti Nyamuk } & \multirow{3}{*}{$\begin{array}{r}4,580 \\
(1,811- \\
11,582)\end{array}$} \\
\hline Kurang Baik & 26 & 70,3 & 11 & 29,7 & 37 & 100,0 & 0,00 & \\
\hline Baik & 16 & 34,0 & 31 & 66,0 & 47 & 100,0 & 2 & \\
\hline \multicolumn{8}{|c|}{$\begin{array}{l}\text { Perilaku Pemberantasan Sarang } \\
\text { Nyamuk }\end{array}$} & \multirow{4}{*}{$\begin{array}{c}3,100 \\
(1,240- \\
7,751)\end{array}$} \\
\hline Tidak & & & & & & & \multirow{3}{*}{$\begin{array}{c}0,02 \\
5\end{array}$} & \\
\hline $\begin{array}{l}\text { Melakukan } \\
\text { PSN }\end{array}$ & 31 & 60,8 & 20 & 39,2 & 51 & 100,0 & & \\
\hline $\begin{array}{l}\text { Melakukan } \\
\text { PSN }\end{array}$ & 11 & 33,3 & 22 & 66,7 & 33 & 100,0 & & \\
\hline $\begin{array}{l}\text { Keberadaan } \\
\text { Place }\end{array}$ & $\lg$ & & & & & & & \multirow{3}{*}{$\begin{array}{r}4,000 \\
(1,614- \\
9,910)\end{array}$} \\
\hline Ada & 28 & 66,7 & 14 & 33,3 & 42 & 100,0 & 0,00 & \\
\hline Tidak ada & 14 & 33,3 & 28 & 66,7 & 42 & 100,0 & 5 & \\
\hline
\end{tabular}

\section{B. Pembahasan}

\section{Hubungan Umur dengan Kejadian Demam Berdarah Dengue di Kabupaten Serdang Bedagai Tahun 2020}

Berdasarkan hasil analisis hubungan antara umur dengan kejadian demam berdarah diketahui bahwa tidak ada hubungan yang signifikan antara umur dengan kejadian demam berdarah dengue pada anak di Kabupaten Serdang Bedagai dengan nilai $p=1,000$ ( $p>0,05)$. Hal ini berarti bahwa anak dengan umur 0 sampai dengan 17 tahun sama-sama berisiko untuk terkena demam berdarah dengue disebabkan karena anak yang memiliki umur 0 sampai 17 tahun masuk dalam kategori muda secara daya tahan tubuh memang cenderung lebih rentan. dibandingkan dengan yang memiliki umur kategori tua.

Penelitian ini juga sejalan dengan penelitian (Permatasari, Ramaningrum, \& Novitasari, 2013) yang menunjukkan bahwa tidak ada hubungan signifikan antara umur dengan derajat infeksi dengue $(\mathrm{p}=0,815)$. 


\section{Hubungan Jenis Kelamin dengan Kejadian Demam Berdarah Dengue di Kabupaten Serdang Bedagai Tahun 2020}

Hasil analisis hubungan antara jenis kelamin dengan kejadian demam berdarah diketahui bahwa tidak ada hubungan antara jenis kelamin dengan kejadian demam berdarah dengue pada anak di Kabupaten Serdang Bedagai $(\mathrm{p}=0,511)$.

Hasil peneltian (Umaya, Faisya, \& Sunarsih, 2013) yang mengemukakan bahwa tidak ada hubungan antara jenis kelamin terhadap kejadian DBD di wilayah kerja Puskesmas Talang Ubi Pendopo Tahun 2012. Hal ini dapat dilihat dari nilai $\mathrm{p}$ - value $=0.996$ ( $\mathrm{p}$ value $>0.05$ ). Ini menunjukkan bahwa jenis kelamin tidak memiliki hubungan terhadap kejadian DBD. Tidak adanya hubungan antara jenis kelamin dengan kejadian DBD ini dikarenakan baik perempuan maupun laki-laki memiliki potensi yang sama untuk terkena penyakit DBD. Hasil penelitian (Hikmah, 2015) yang menyebutkan bahwa tidak ada hubungan antara jenis kelamin penderita dengan Kejadian Kematian Akibat DBD dengan nilai $\mathrm{p}=$ 0,611 ( $\mathrm{p}>0,05$ ). Hasil penelitian ini sejalan juga dengan peneltian (Umaya et al., 2013) yang mengemukakan bahwa tidak ada hubungan antara jenis kelamin terhadap kejadian DBD di wilayah kerja Puskesmas Talang Ubi Pendopo Tahun 2012. Hal ini dapat dilihat dari nilai $\mathrm{p}-$ value $=0.996(\mathrm{p}$ value $>0.05)$

\section{Hubungan Kebiasaan Memakai Obat Anti Nyamuk dengan Kejadian Demam Berdarah Dengue di Kabupaten Serdang Bedagai Tahun 2020}

Penelitian ini menunjukkan hasil yang signifikan yaitu adanya hubungan yang bermakna antara kebiasaan memakai obat anti nyamuk dengan kejadian demam berdarah dengue pada anak di Kabupaten Serdang Bedagai $(p=0,002)$ dengan $\mathrm{OR}=4,580(95 \% \mathrm{CI}=1,811-11,582)$. Hal ini menunjukkan bahwa penduduk yang memiliki kebiasaan memakai obat anti nyamuk yang kurang baik memiliki risiko 4,580 kali terkena DBD dibandingkan dengan penduduk yang memiliki kebiasaan memakai obat anti nyamuk yang baik.

Dari hasil penelitian di lapangan, sebagian anak tidak pernah menggunakan anti nyamuk pada siang hari, tetapi sebaliknya menggunakan anti nyamuk seperti anti nyamuk bakar, menyemprot atau menggunakan kelambu hanya pada malam hari saja, anggapan mereka bahwa pada siang hari lebih banyak beraktifitas sehingga perlindungan terhadap gigitan nyamuk tidak perlu dilakukan. Banyak juga ditemukan bahwa anak tidak biasa memakai lotion anti nyamuk baik di rumah maupun hendak keluar rumah, dan masih banyak ditemukan rumah tidak menggunakan kawat kasa padahal kawat kasa merupakan salah satu yang digunakan untuk mencegah nyamuk masuk ke dalam rumah. Hasil penelitian (Ayun, L.L., Pawenang, 2017) di puskesmas Sekaran menyatakan kebiasaan memakai lotion anti nyamuk secara statistik berpengaruh dengan kejadian DBD $\mathrm{OR}=4,200 ; \mathrm{p}=0,042$. Hasil penelitian ini sejalan dengan penelitian (Sandra, Sofro, Suhartono, Martini, \& Hadisaputro, 2019) yang menyatakan bahwa ada pengaruh kebiasaan memakai obat anti nyamuk terhadap kejadian DBD pada anak dengan $\mathrm{p}=0,001$, OR 4,000; 95\% CI 1,889-8,468. Dari hasil penelitian (Zarkasyi, L, 
Martini, \& Hestiningsih, R, 2015) yang berjudul Hubungan Faktor Host (Umur 6 Bulan-14 Tahun) Dan Keberadaan Vektor Dengan Kejadian Demam Berdarah Dengue di Wilayah Kerja Puskesmas Kedungmundu Semarang hasil uji chisquare yang dilakukan, didapatkan nilai $\mathrm{p}=0,003(\mathrm{p}<0,05)$, berarti ada hubungan antara penggunaan obat anti nyamuk pada usia (6 bulan-14 tahun) dengan kejadian DBD di wilayah kerja Puskesmas Kedungmundu.

\section{Hubungan Perilaku Pemberantasan Sarang Nyamuk dengan Kejadian Demam Berdarah Dengue di Kabupaten Serdang Bedaga Tahun 2020}

Berdasarkan hasil analisis hubungan antara perilaku pemberantasan sarang nyamuk dengan demam berdarah dengue diketahui bahwa ada hubungan yang bermakna $(p=0,025)$ antara perilaku pemberantasan sarang nyamuk dengan kejadian demam berdarah dengue pada anak di Kabupaten Serdang Bedagai dengan $\mathrm{OR}=3,100(95 \% \mathrm{CI}=1,240-7,751)$. Hal ini menunjukkan bahwa penduduk yang tidak melakukan perilaku pemberantasan sarang nyamuk memiliki risiko 3,1 kali terkena DBD dibandingkan dengan penduduk yang melakukan pemberantasan sarang nyamuk.

Pelaksanaan PSN masih mengalami hambatan karena tidak semua masyarakat mau melaksanakan PSN. Kejadian DBD pada penelitian ini berhubungan dengan praktik PSN karena masih banyak masyarakat yang belum mengetahui manfaat pemberantarasan sarang nyamuk sehingga tidak dapat dilaksanakan dengan baik, seperti fungsi dari menguras tempat penampungan air atau menutup tempat penampungan air dengan rapat yang berada di luar rumah, menurut mereka air yang ditampung di luar rumah tidak dipakai untuk keperluan sehari-hari hanya untuk menyiram halaman, tanaman dan tempat minum hewan peliharaan sehingga tidak perlu dibersihkan ataupun di tutup. Masyarakat juga tidak mengetahui bahwa penampungan dispenser dan tendon belakang kulkas juga dapat menjadi tempat perkembangbiakkan jentik nyamuk Aedes Aegypti sehingga mereka jarang memeriksa atau membuang air pada tampungan dispenser dan tendon belakang kulkas. Hasil penelitian juga menunjukkan hanya sedikit responden yang membersihkan talang air dan saluran air masih banyak yang tersumbat atau tidak mengalir lancar. Masyarakat juga sedikit sekali menabur bubuk abate dikarenakan kurangnya dukungan atau ajakan dari pemerintah setempat untuk mengajak seluruh masyarakat melakukannya.

Hasil penelitian ini sejalan dengan penelitian (Pangemanan, Kundre, \& Lolong, 2016) yang menyatakan bahwa terdapat hubungan antara tindakan pemberantasan sarang nyamuk (PSN) dengan kejadian demam berdarah dengue (DBD) $(\mathrm{p}=0,048)$. Hasil penelitian ini juga sejalan dengan (Saleh, Aeni, Gafur, \& Basri, 2018) pada penelitian yang berjudul Hubungan Pemberantasan Sarang Nyamuk (PSN) dengan Keberadaan Jentik Nyamuk Aedes aegypti di Wilayah Kerja Puskesmas Pancana Kab. Barru yang melaporkan bahwa ada hubungan antara menguras tempat penampungan air dengan keberadaan jentik nyamuk Aedes aegypti ( $\mathrm{p}$ value $=0,006$ ), ada hubungan antara menutup tempat 
penampungan air dengan keberadaan jentik nyamuk Aedes aegypti $\quad(\mathrm{p}$ value $=$ 0,000) dan ada hubungan antara mengubur barang - barang bekas dengan keberadaan jentik nyamuk Aedes aegypti ( $\mathrm{p}$ value $=0,000)$.

\section{Hubungan Keberadaan Breeding Place dengan Kejadian Demam Berdarah Dengue di Kabupaten Serdang Bedagai Tahun 2020}

Pada variabel keberadaan breeding place diketahui bahwa yang ditemukan keberadaan breeding place nya $\geq 7$ seperti tempayan, ember, drum, talang/saluran air bak mandi, dispenser, tendon belakang kulkas, tempat minum hewan piaraan dan ban bekas yaitu sebanyak 42 orang $(50,0 \%)$ dan yang ditemukan keberadaan breeding place nya $<7$ seperti tempayan, ember, drum, talang/saluran air dalam, bak mandi, dispenser, tendon belakang kulkas, tempat minum hewan piaraan dan ban bekas yaitu sebanyak 42 orang $(50,0 \%)$. Berdasarkan hasil analisis hubungan antara keberadaan breeding place dengan demam berdarah dengue diketahui bahwa ada hubungan antara keberadaan breeding place dengan kejadian demam berdarah dengue pada anak di Kabupaten Serdang Bedagai $(\mathrm{p}=0,005)$ dengan OR $=4,000(95 \% \mathrm{CI}=1,614-9,910)$. Hal ini menunjukkan bahwa penduduk yang ada ditemukan pada keberadaan breeding place memiliki risiko 4,000 kali terkena DBD dibandingkan dengan penduduk yang tidak ditemukan keberadaan breeding place. Hasil ini menunjukkan semakin banyak terdapat breeding places akan meningkatkan risiko terhadap kejadian DBD.

Hasil pengamatan di lapangan, tempat penampungan air lebih banyak ditemukan pada kelompok kasus daripada kelompok kontrol dan lebih banyak ditemukan di luar rumah yang dibiarkan terbuka serta jarang dibalikkan dan bahkan ada yang tidak pernah membersihkannya karena fungsinya yang menurut mereka hanya untuk menyiram tanaman, menjadi tempat sampah dan bukan dipakai untuk keperluan sehari-hari, seperti mandi. Hal ini dapat menyebabkan tempat penampungan air dapat menjadi tempat perkembangbiakan nyamuk aedes aegypti.

Hasil penelitian ini sejalan dengan penelitian (Widyorini, Wahyuningsih, \& Murwani, 2016) yang berjudul faktor keberadaan breeding place dengan kejadian demam berdarah dengue di Semarang yang menunjukkan bahwa ada hubungan keberadaan breeding place dengan kejadian $\mathrm{DBD}(\mathrm{p}=0,048$ dan nilai $\mathrm{OR}=$ 3,143). Hasil penelitian ini juga sejalan dengan penelitian (Puteri, Darundiati, \& Dewanti, 2018) yang berjudul Hubungan Breeding Place dan Resting Place terhadap Kejadian Demam Berdarah Dengue di Kecamatan Semarang Barat meenunjukkan bahwa ada hubungan antara keberadaan breeding place positif jentik dengan kejadian demam berdarah dengue dengan nilai $\mathrm{p}=0,001$ dan $\mathrm{OR}$ 10,389 (95\% CI = 2,728 - 39,56). Pada penelitian Anggreini, Heridadi \& Widana tahun 2018 yang berjudul faktor resiko (breeding place, resting placae, perilaku kesehatan lingkungan dan kebiasaan hidup) pada KLB DBD di Kecamatan Cikupa Kabupaten Tanggerang diperoleh hasil hubungan yang signifikan antara 
keberadaan breeding places berjumlah 3 atau lebih disekitar rumah disekitar rumah dengan KLB DBD yang terjadi di Kecamatan Cikupa Kabupaten Tangerang. OR yang diperoleh dalam penelitian ini yaitu sebesar 8,531 (95\% CI 3,431-21,209). Hasil ini menunjukkan semakin banyak breeding places akan meningkatkan risiko terhadap KLB DBD di Kecamatan Cikupa.

\section{Kesimpulan}

Kesimpulan hasil temuan penelitian ini berdasarkan hasil analisis bivariat yang dilakukan diperoleh hasil bahwa variabel kebiasaan memakai obat anti nyamuk, perilaku pemberantasan sarang nyamuk dan keberadaan breeding place mempunyai hubungan yang bermakna dengan kejadian demam berdarah dengue di Kabupaten Serdang Bedagai Tahun 2020. Sedangkan umur dan jenis kelamin tidak memiliki hubungan dengan kejadian demam berdarah dengue di Kabupaten Serdang Bedagai. Maka, dari hasil penelitian tersebut disarankan bagi masyarakat Kabupaten Serdang Bedagai agar selalu membiasakan memakai obat anti nyamuk di rumah namun tidak disarankan menggunakan obat anti nyamuk bakar dikarenakan tidak ramah lingkungan dan sebaiknya masyarakat menggunakan lotion anti nyamuk, elektrik, obat anti nyamuk semprot dan sebaiknya di rumah menggunakan kawat kasa. Mengurangi tempat penampungan air, menguras TPA secara rutin, dan melakukan pemberantasan sarang nyamuk seminggu sekali. 
Hetti Citra Marbun, Sri Malem Indirawati, Nurmaini

\section{BIBLIOGRAFI}

Ayun, L.L., Pawenang, T. E. (2017). Hubungan antara Faktor Fisik dan Perilaku dengan Kejadian Demam Berdarah Dengue (DBD) Di Wilayah Kerja Puskesmas Sekaran, Kecamatan Gunungpati, Kota Semarang. Jurnal Health Perspective, 2(1).Google Scholar

Anggraeni, P., Heridadi., \& Widana, K. (2018). Faktor Resiko (Breeding Place, Resting Place, Perilaku Kesehatan Lingkungan dan Kebiasaan Hidup) pada KLB DBD di Kecamatan Cikupa Kabupaten Tanggerang. Jurnal Manajemen Bencana, 4 (1).Google Scholar

Bedagai, Badan Pusat Statistik Kabupaten Serdang. (2018). Kabupaten Serdang Bedagai dalam Angka 2017. BPS Kabupaten Serdang Bedagai, Sumatera Utara.Google Scholar

Golberg. (1999). Epidemiologi Penyakit Menular. Diakses Dari File:///C:/Users/HP/Downloads/Irwan-Buku-Epidemiologi-Penyakit-Menular.Pdf.

Hikmah, Mamluatul. (2015). Faktor yang berhubungan dengan kejadian kematian akibat demam berdarah dengue. Unnes Journal of Public Health, 4(4). Google Scholar

Kementerian Kesehatan RI. (2019). Profil Kesehatan Indonesia. Diakses Dari Https://Pusdatin.Kemkes.Go.Id/Resources/Download/Pusdatin/Profil-KesehatanIndonesia/Profil-Kesehatan-Indonesia-2019.Pdf.

Pangemanan, Helly Conny, Kundre, Rina, \& Lolong, Jill. (2016). Hubungan Tindakan Pemberantasan Sarang Nyamuk (PSN) dengan Kejadian Demam Berdarah Dengue (DBD) di Desa Watutumou I, II \& III Wilayah Kerja PUSKESMAS Kolongan. Jurnal Keperawatan, 4(2). Google Scholar

Permatasari, Devi Yanuar, Ramaningrum, Galuh, \& Novitasari, Andra. (2013). Hubungan status Gizi, umur, dan jenis kelamin dengan derajat infeksi dengue Pada anak. Jurnal Kedokteran Muhammadiyah, 2(1).Google Scholar

Puteri, Tika Adelia Nurkholis, Darundiati, Yusniar Hanani, \& Dewanti, Nikie Astorina Yunita. (2018). Hubungan breeding place dan resting place terhadap kejadian demam berdarah dengue (DBD) Di Kecamatan Semarang Barat. Jurnal Kesehatan Masyarakat (Undip), 6(6), 369-377.Google Scholar

Saleh, Muhammad, Aeni, Syahratul, Gafur, Abdul, \& Basri, Syahrul. (2018). Hubungan Pemberantasan Sarang Nyamuk (PSN) dengan Keberadaan Jentik Nyamuk Aedes aegypti di Wilayah Kerja Puskesmas Pancana Kab. Barru. Jurnal Higiene. ISSN, 2541-5301.Google Scholar

Sandra, Tuti, Sofro, Muchlis A. U., Suhartono, Suhartono, Martini, Martini, \& Hadisaputro, Suharyo. (2019). Faktor-faktor yang Berpengaruh terhadap Kejadian Demam Berdarah Dengue pada Anak Usia 6-12 TAhun Di Kecamatan tembalang. Jurnal Epidemiologi Kesehatan Komunitas, 4(1), 1-10.Google Scholar 
Umaya, Rizza, Faisya, Ahmad Fickry, \& Sunarsih, Elvi. (2013). Hubungan Karakteristik Pejamu, Lingkungan Fisik Dan Pelayanan Kesehatan Dengan Kejadian Demam Berdarah Dengue (DBD) Di Wilayah Kerja Puskesmas Talang Ubi Pendopo Tahun 2012. Jurnal Ilmu Kesehatan Masyarakat, 4(3).Google Scholar

Widyorini, Prasti, Wahyuningsih, Nur Endah, \& Murwani, Retno. (2016). Faktor Keberadaan Breeding Place Dengan Kejadian Demam Berdarah Dengue Di Semarang. Jurnal Kesehatan Masyarakat (Undip), 4(5), 94-99.Google Scholar

World Health Organization (WHO). (2015). Demam Berdarah. Diakses Dari Http://Eprints.Ums.Ac.Id/71407/3/BAB\%20I.Pdf.

Zarkasyi. L., Martini., Hestiningsih. R., (2015). Hubungan Faktor Host (Umur 6 Bulan14 Tahun) Dan Keberadaan Vektor Dengan kejadian Demam Berdarah Dengue Di wilayah Kerja Puskesmas Kedungmundu Semarang. Jurnal Kesehatan Masyarakat, 3(3). Google Scholar

Copyright holder :

Hetti Citra Marbun, Sri Malem Indirawati dan Nurmaini (2021)

First publication right :

Journal Syntax Idea

This article is licensed under: 